\title{
Epigenetic profiling to environmental stressors in model and non-model organisms: Ecotoxicology perspective
}

\author{
Nivedita Chatterjee, Jiwan Gim, Jinhee Choi \\ School of Environmental Engineering, University of Seoul, 163 Seoulsiripdaero, Dondaemun-gu, Seoul 02504, Republic of Korea
}

Epigenetics, potentially heritable changes in genome function that occur without alterations to DNA sequence, is an important but understudied component of ecotoxicology studies. A wide spectrum of environmental challenge, such as temperature, stress, diet, toxic chemicals, are known to impact on epigenetic regulatory mechanisms. Although the role of epigenetic factors in certain biological processes, such as tumourigenesis, has been heavily investigated, in ecotoxicology field, epigenetics still have attracted little attention. In ecotoxicology, potential role of epigenetics in multi- and transgenerational phenomenon to environmental stressors needs to be unrevealed. Natural variation in the epigenetic profiles of species in responses to environmental stressors, nature of dose-response relationships for epigenetic effects, and how to incorporate this information into ecological risk assessment should also require attentions. In this review, we presented the available information on epigenetics in ecotoxicological context. For this, we have conducted a systemic review on epigenetic profiling in response to environmental stressors, mostly chemical exposure, in model organisms, as well as, in ecotoxicologically relevant wildlife species.

Keywords: epigenetics, ecotoxicology, transgenerational effect, environmental stressors, wildlife species

\section{INTRODUCTION}

Epigenetics refers to potentially heritable changes in genome function, such as gene activity or silencing, that occur without alterations to DNA sequence [1-3]. Commonly studied epigenetic mechanisms include chromatin remodeling (DNA methylation and histone modifications) and RNA-mediated modifications (e.g. non-coding RNA and microRNA) [4]. Environmental challenges can have immediate impact on epigenetic regulation in an individual or a population, and can be transmitted through mitotic and meiotic cell divisions and passed on to subsequent generations [3]. While certain epigenetic changes can result in increased risk of development of certain diseases, such as neurological disorders and cancers either immediately or at a later stage in life (adult onset of disease), others can be beneficial leading to plasticity and adaptation [2]. As a wide spectrum of environmental challenges

Received: August 29, 2018 Accepted: September 19, 2018

Corresponding author: Jinhee Choi

School of Environmental Engineering, University of Seoul, 163 Seoulsiripdaero, Dondaemun-gu, Seoul, 02504, Korea

E-mail: jinhchoi@uos.ac.kr

This article is available from: http://e-eht.org/ (e.g. temperature, stress, diet, toxins) are known to impact on epigenetic regulatory mechanisms, epigenetics is an important component of ecotoxicology studies, it is however understudied so far.

Although the role of epigenetic factors in certain biological processes, such as tumourigenesis, has been heavily investigated [5-6], there are still areas that have either been neglected or have attracted little attention. For example, the impact of variation in the degree of methylation of otherwise identical genes (epialleles) on phenotypic and physiological endpoints in organisms is not yet broadly appreciated, in part because the phenomenon of epigenetics is not typically part of the design of physiological investigations. Furthermore, still enigmatic and somewhat ill-defined is the relationship between the overarching concept of epigenetics and interesting transgenerational phenomena (e.g. 'maternal/parental effects') that alter the physiological phenotype of subsequent generations. The lingering effect on subsequent generations of an initial environmental disturbance in parent animals can be profound, with genes continuing to be variously silenced or expressed without an associated change in gene sequence for many generations. Other areas that require further attention are: how natural variation in the epigenetic profiles of species 
alters their responses to environmental stressors, what evidence is available on the nature of dose-response relationships for epigenetic effects, and how to incorporate this information into ecotoxicology studies, such as chemical risk assessment.

\section{CURRENT STATUS OF EPIGENETICS IN ECOTOXICOLOGY}

Epigenetics parameters (markers) include DNA methylation, histone modifications (methylation, acetylation, phosphorylation, ubiquitinylation etc.), non-coding RNAs and newest member of this group is epitranscriptome [7]. Epigenetic mechanisms were first described as major agents in development and differentiation, but they appear as key components of the organism's response to environmental changes by modulating gene expression and other genome functions. Many organisms respond to environmental conditions by showing phenotypic plasticity, which means producing different phenotypes from the same genotype [8-9]. Increasing evidence shows that at least part of this phenotypic plasticity in animals exposed to environmental factors (such as diet, temperature, etc.) is mediated by epigenetics in a wide variety of organisms including vertebrates, insects and plants [10-14]. Environmental epigenetics investigates the cause-effect relationships between specific environmental factors that trigger adaptive responses in the cell and changes in epigenetic modifications. Given the dynamic and potentially reversible nature of the different types of epigenetic marks, environmental epigenetics constitutes a promising venue for developing fast and sensible biomonitoring programs. Indeed, several epigenetic biomarkers have been successfully developed and applied in traditional model organisms (e.g., human and mouse). Nevertheless, the lack of epigenetic knowledge in other ecologically and environmentally relevant organisms has hampered the application of these tools in a broader range of ecosystems. Fortunately, that scenario is now changing thanks to the growing availability of complete reference genome sequences and the development of high-throughput DNA sequencing and bioinformatics tools.

Toxico-epigenomics is the study of epigenomic changes caused by exposure to toxins/toxicants. Several studies (mostly in humans, primates and rodents) report epigenetic modifications related to exposure to chemicals and their relationship with the appearance of cancer [15]. Moreover, environmental exposures to chemicals can also affect the epigenetic status of ecotoxicologically relevant species of fish, plants and invertebrates [3]. Anthropogenic substances present in the environ- ment have been found to not only chemically modify DNA and/or histones, but also affect (either by stimulation or inhibition) the enzymes activities involved in epigenetic control.

A summary of the recent published reports on applications of epigenetics to ecotoxicology studies can be found in Tables 1 and 2 . These studies reinforce the idea that environmental stressors affect epigenetic markers, but the exact mechanisms of action are still unknown and further investigations are required. Environmental epigenetic analyses have extraordinary potential to advance our understanding of cellular and organismal responses to ecological challenges, and could serve as a promising source of rapid and sensitive tools for pollution biomonitoring of ecotoxicity species. The characterization of potentially hazardous substances may create a new field in ecotoxicology, but it would require the development of suitable epigenetic biomarkers both in mammals including humans, in other established model organisms and in environmentally-relevant species. In recent years, epigenetic tools have gained traction in ecotoxicology studies; the availability of genome assemblies for ecotoxicology-relevant species, and the wide conservation of known epigenetic components and mechanisms, will help drive further advances. In this regard, some researchers have already suggested that the "epigenetic foot-print" of an organism could be used as a tool to identify previous exposures to pollutants [16]. However, epigenetic knowledge and applications in ecologically relevant organisms still lags far behind mammalian and other model organisms. Importantly, we currently have a very limited understanding of the impact of environmental challenges on epigenetic mechanisms, subsequent phenotypic effects, and how often they are transmitted across generations. In order to fully achieve the promise of ecotoxicology studies, epigenetic mechanisms, in parallel with genetic mechanisms, should be considered in ecological risk assessments and sensible biomonitoring programs[16-17]

\section{EPIGENETIC PROFILING IN RESPONSE TO ENVIRONMENTAL STRESS IN MODEL ORGANISMS}

Tables 1 presented the available information on epigenetic profiling in response to environmental chemical exposure in model organisms. Most environmental epigenetic studies were conducted on zebrafish, Danio rerio, followed by water flea, Daphnia magna. Studies on the nematode, Caenorhabditis elegans, and fruit fly, Drosophila melanogaster were also conducted. Most of D. rerio and D. magna studies were on DNA methylation, whereas, most of $C$. elegans studies were on non-cording RNA and histone modifications. 


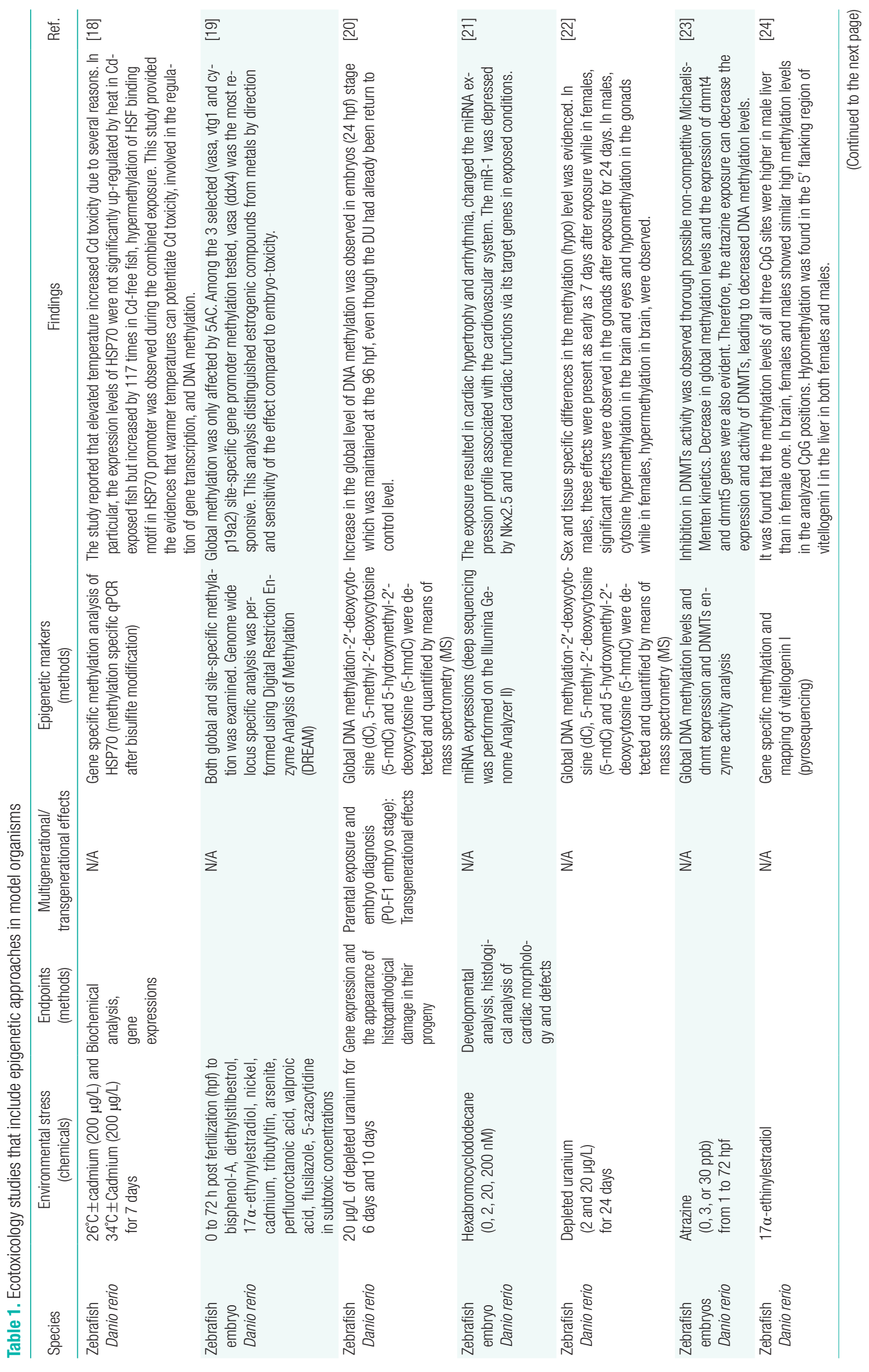




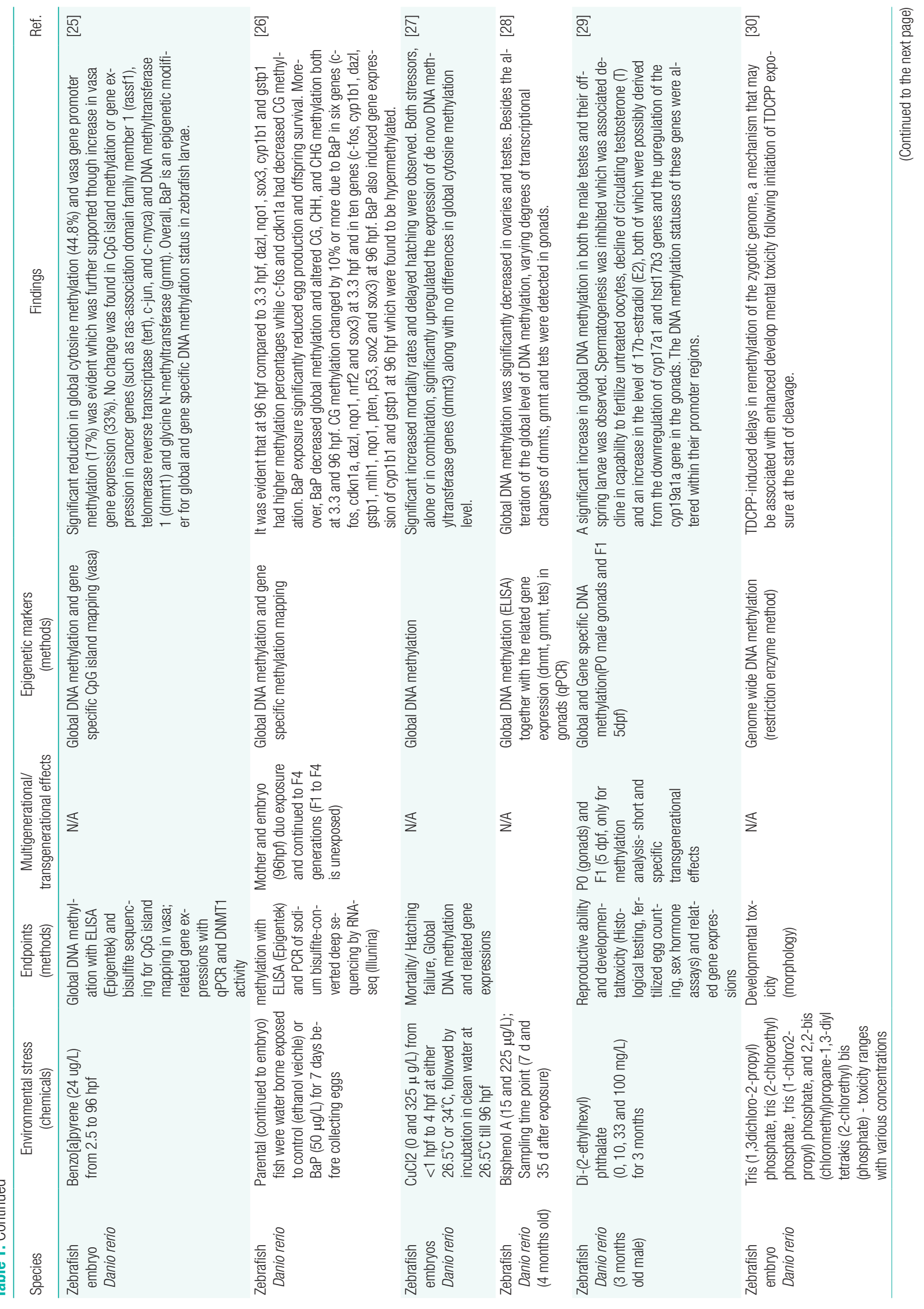




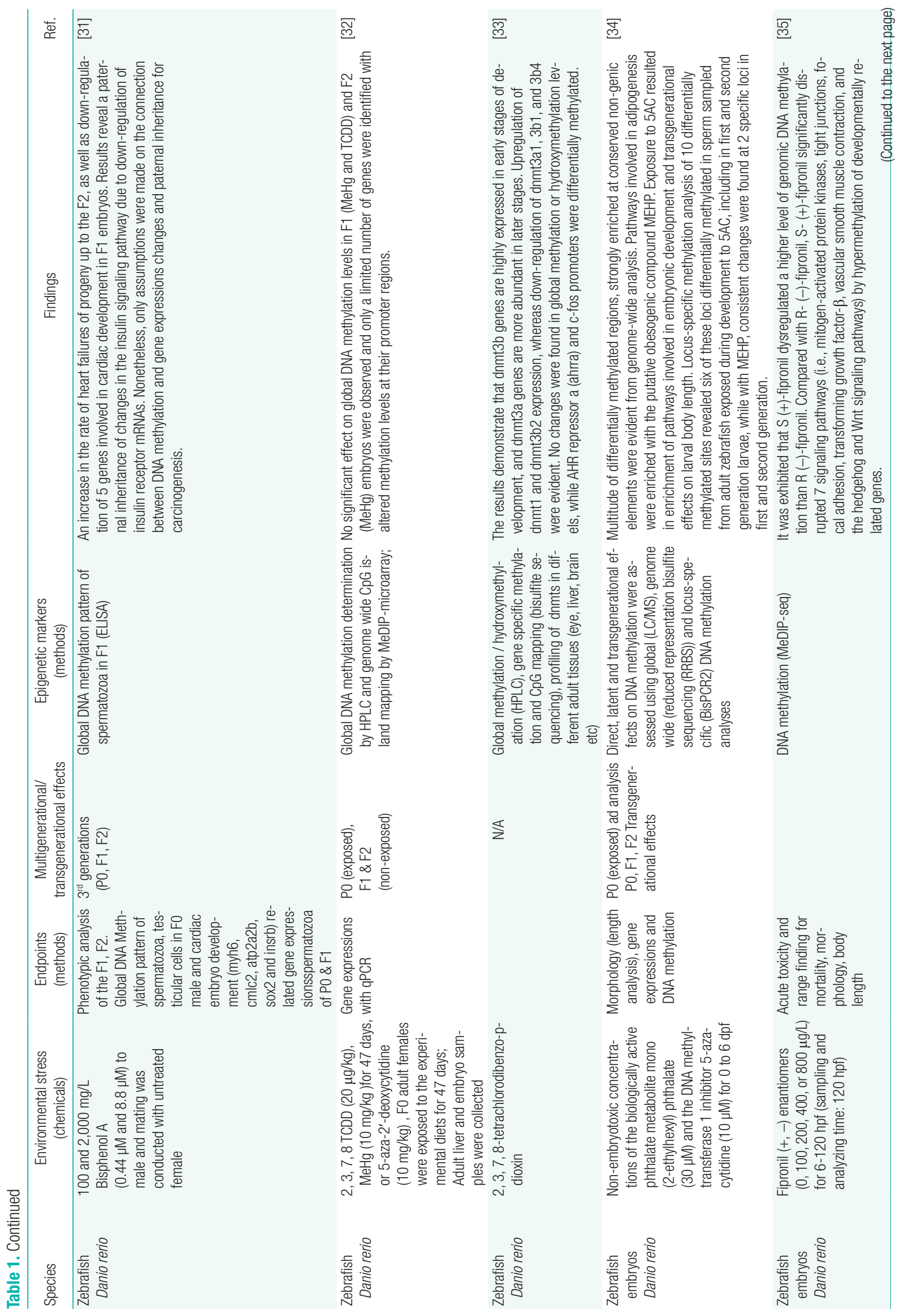




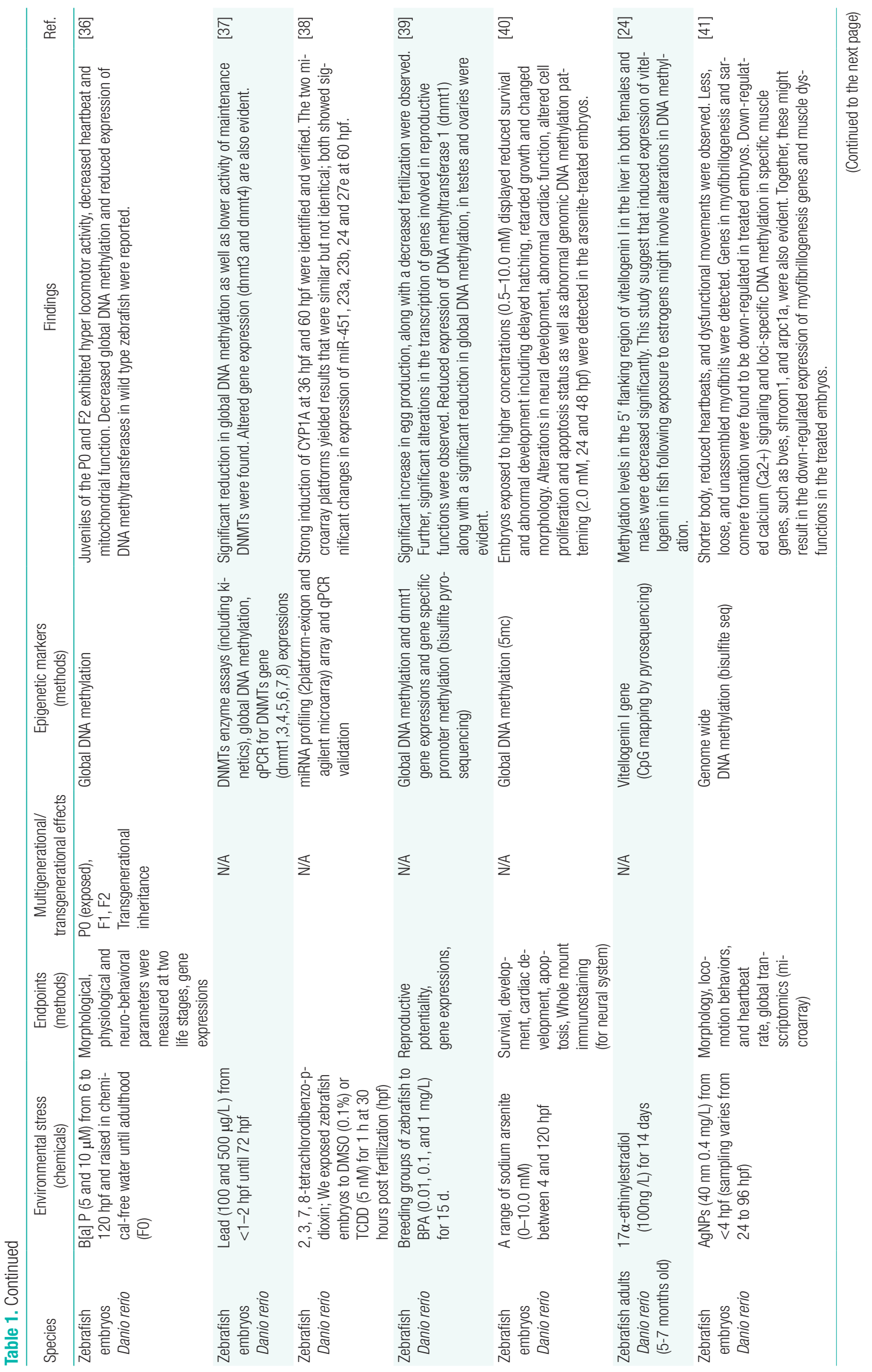




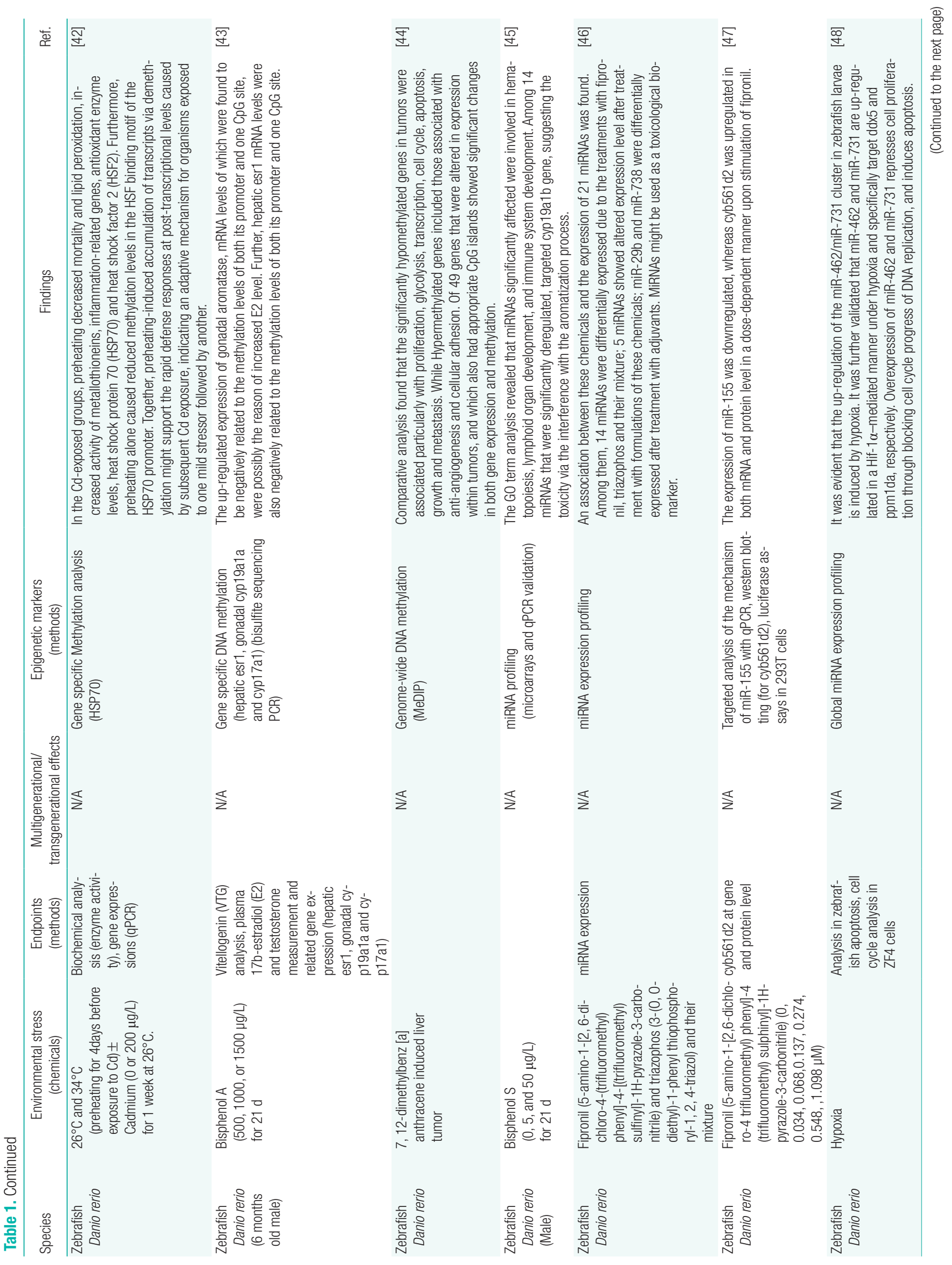




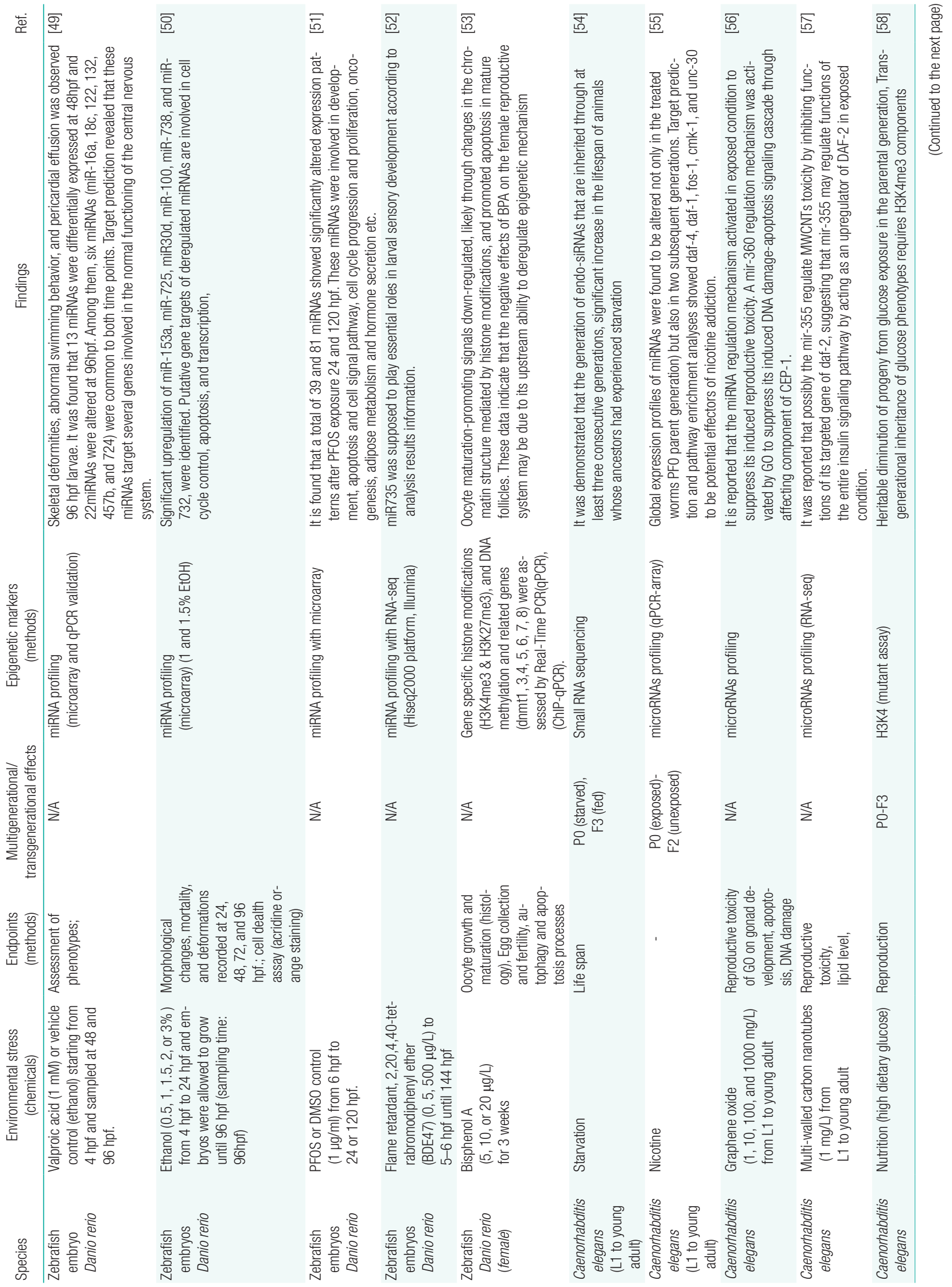




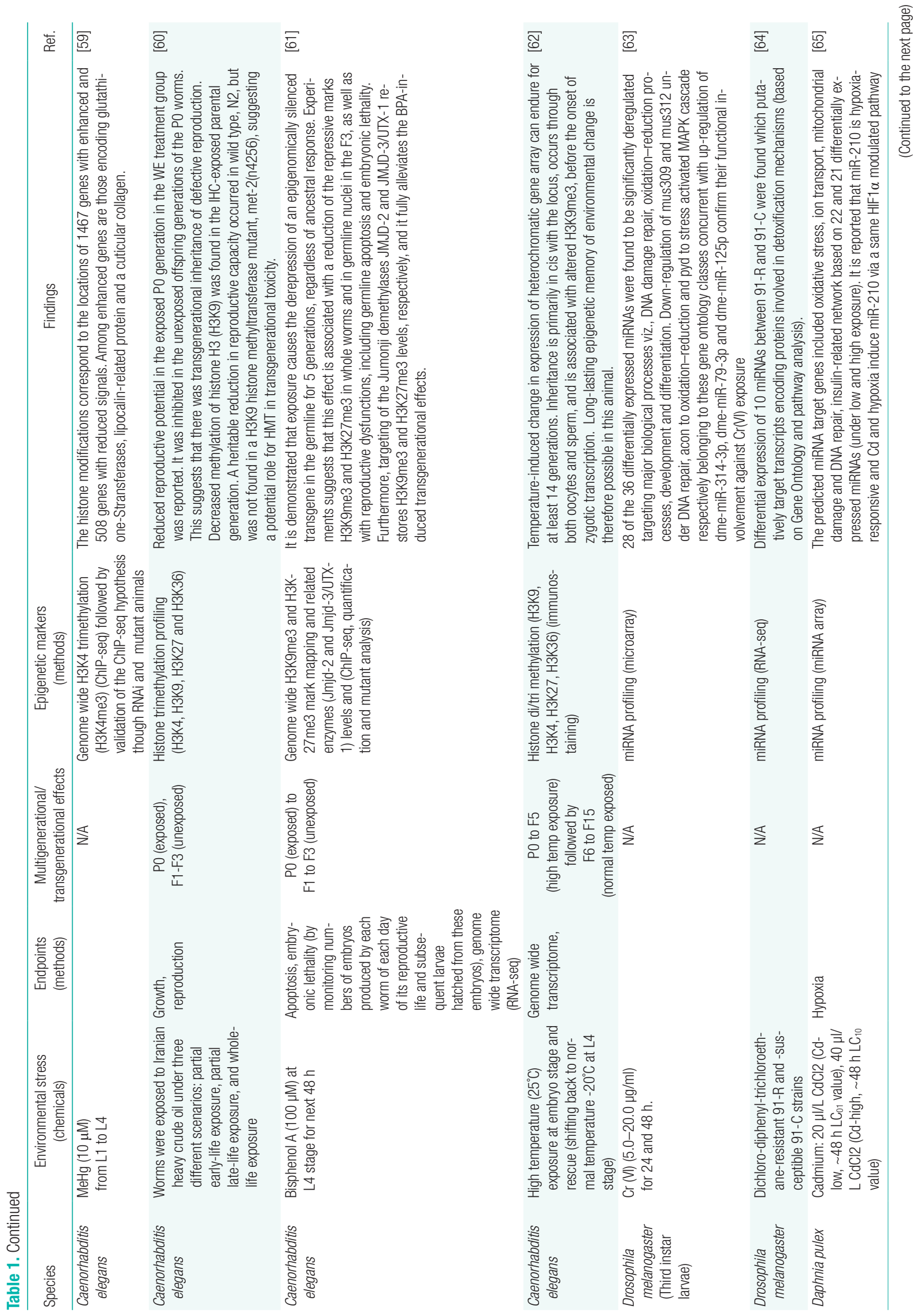




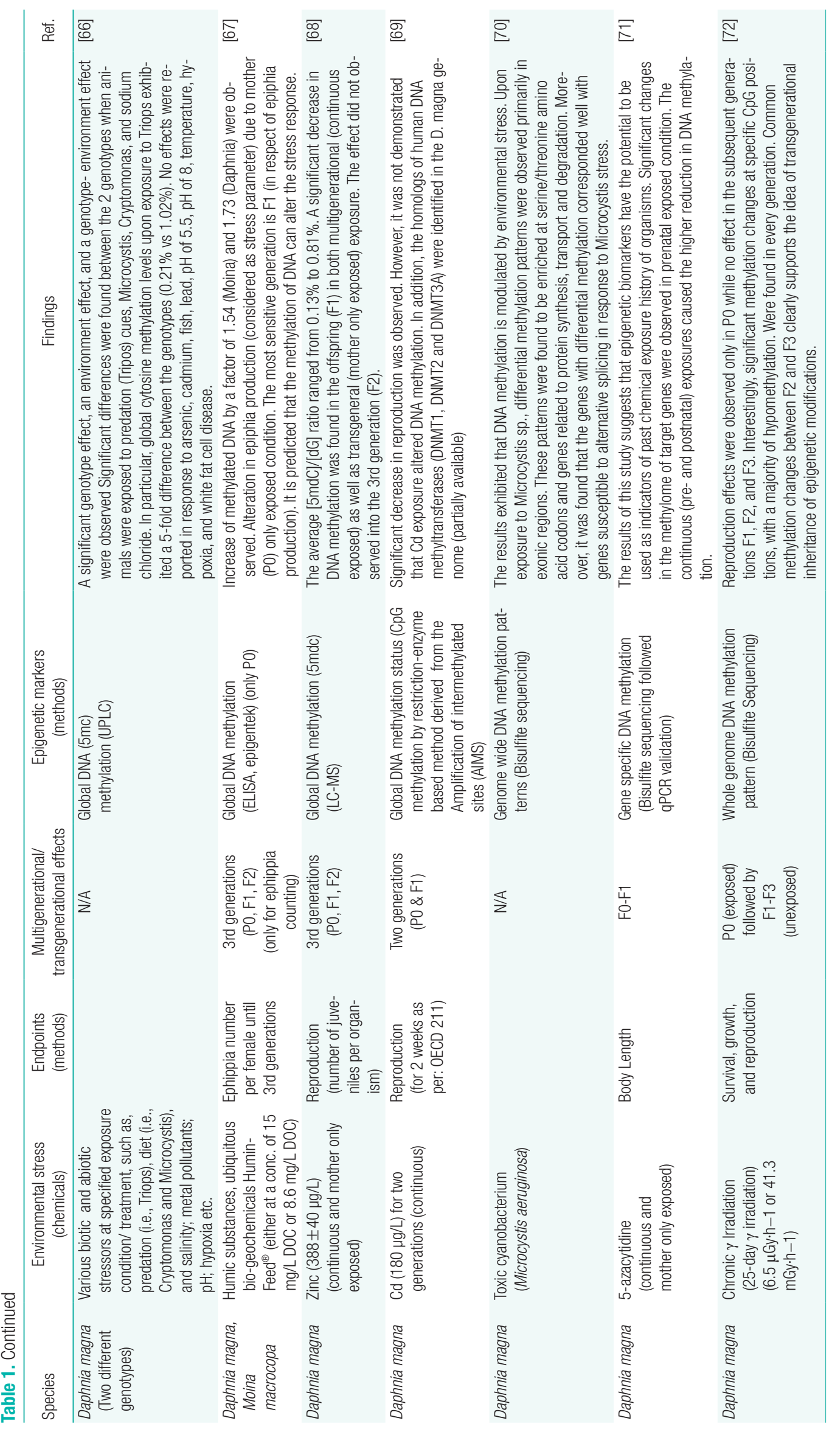




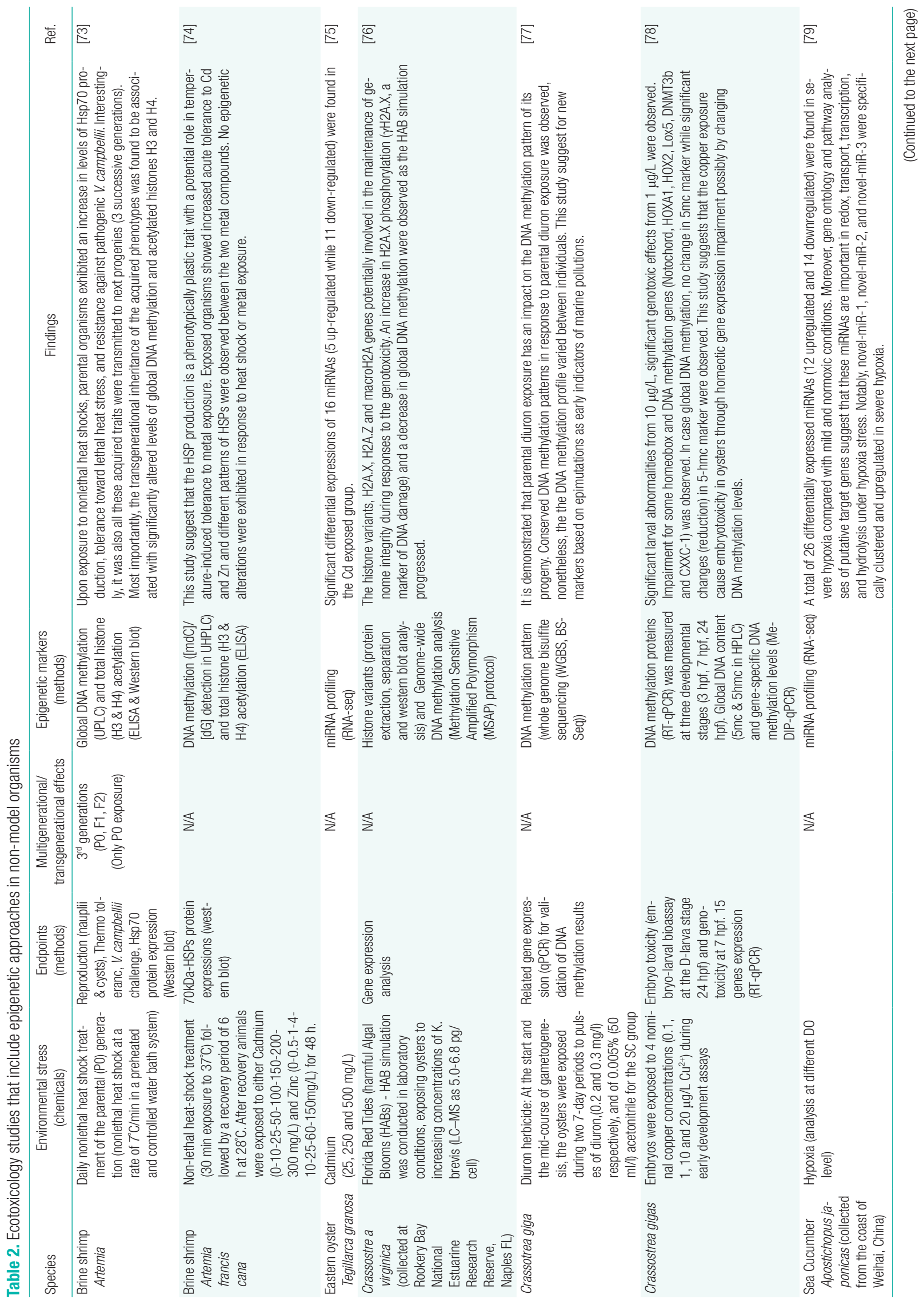




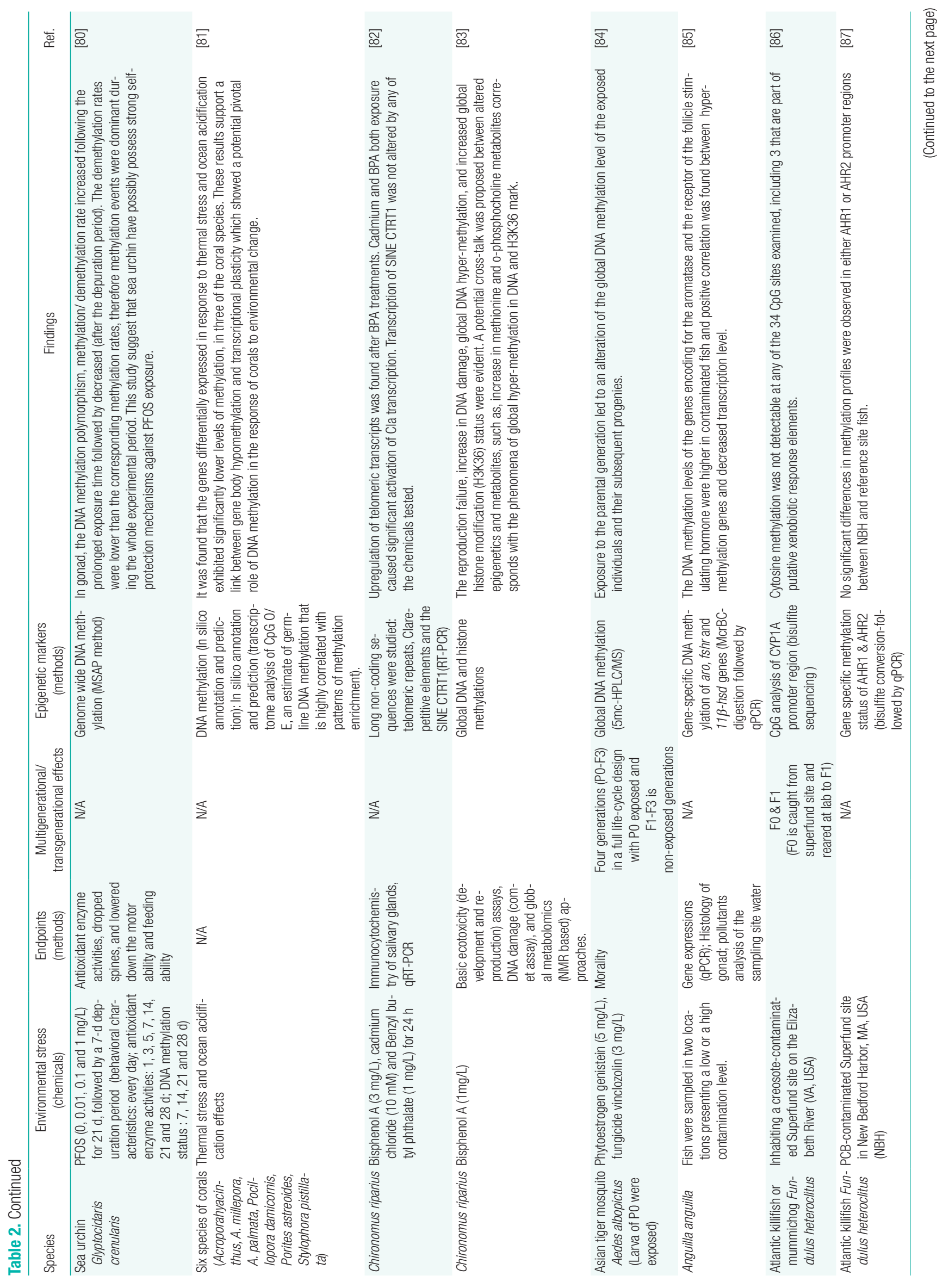




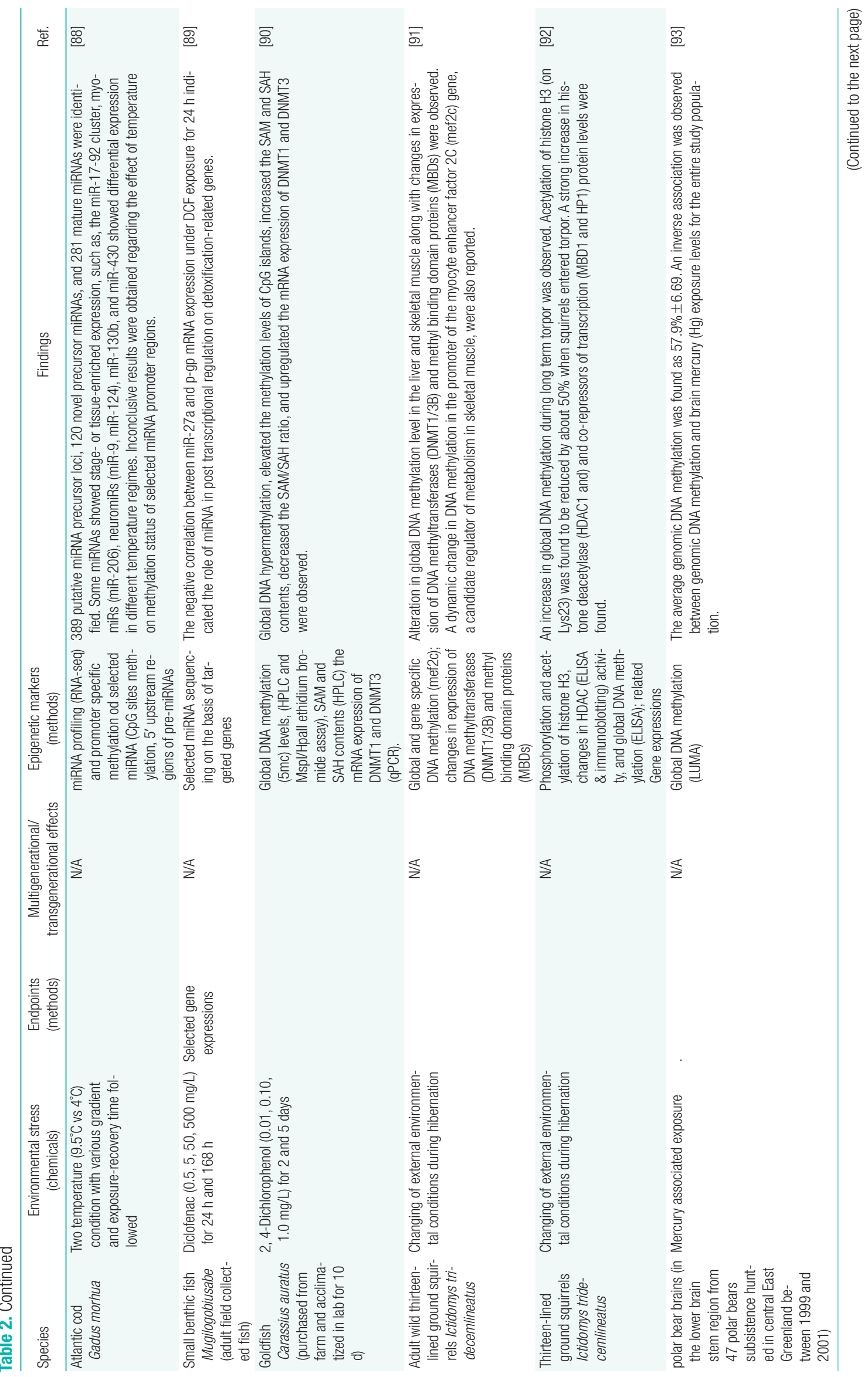




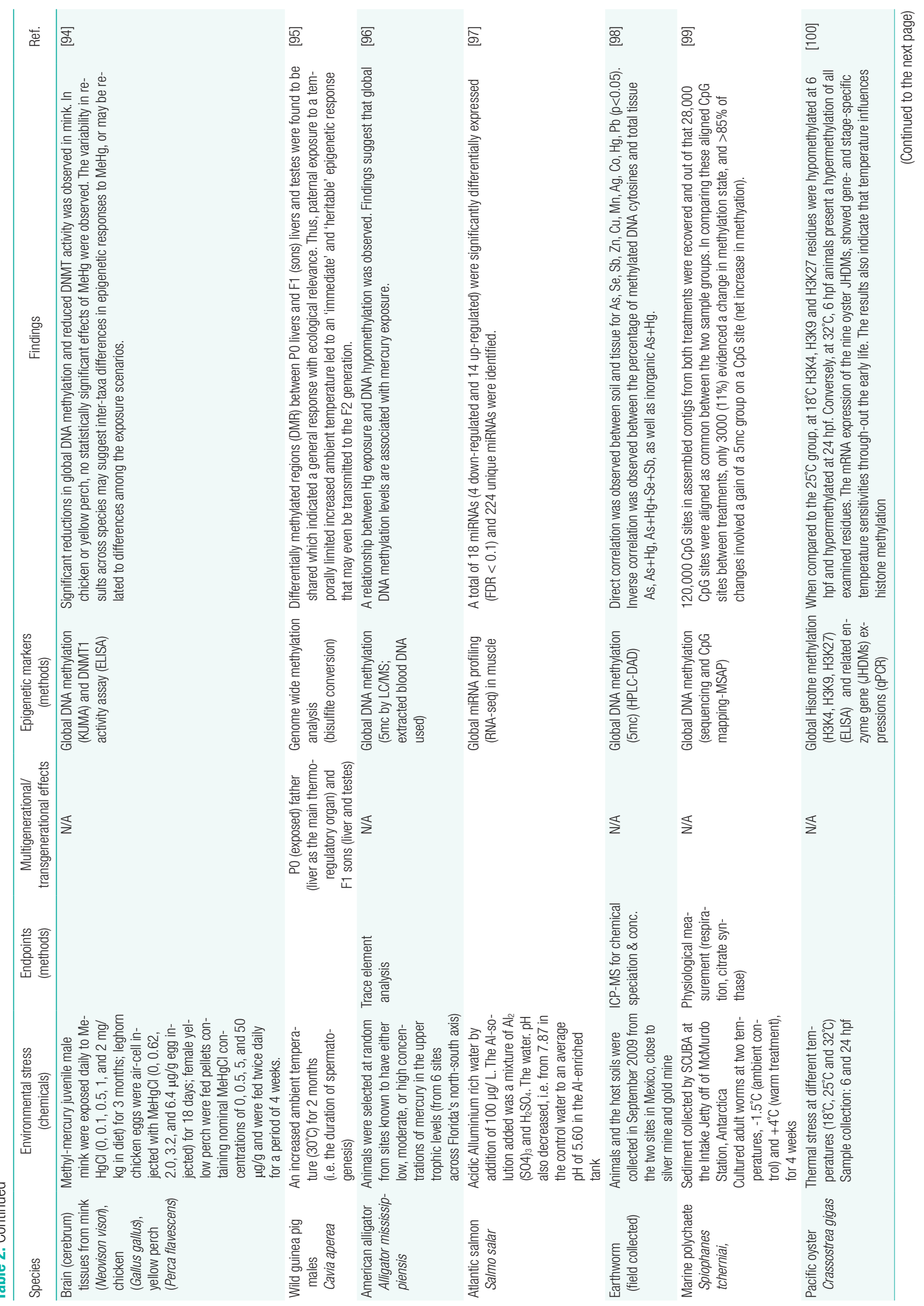




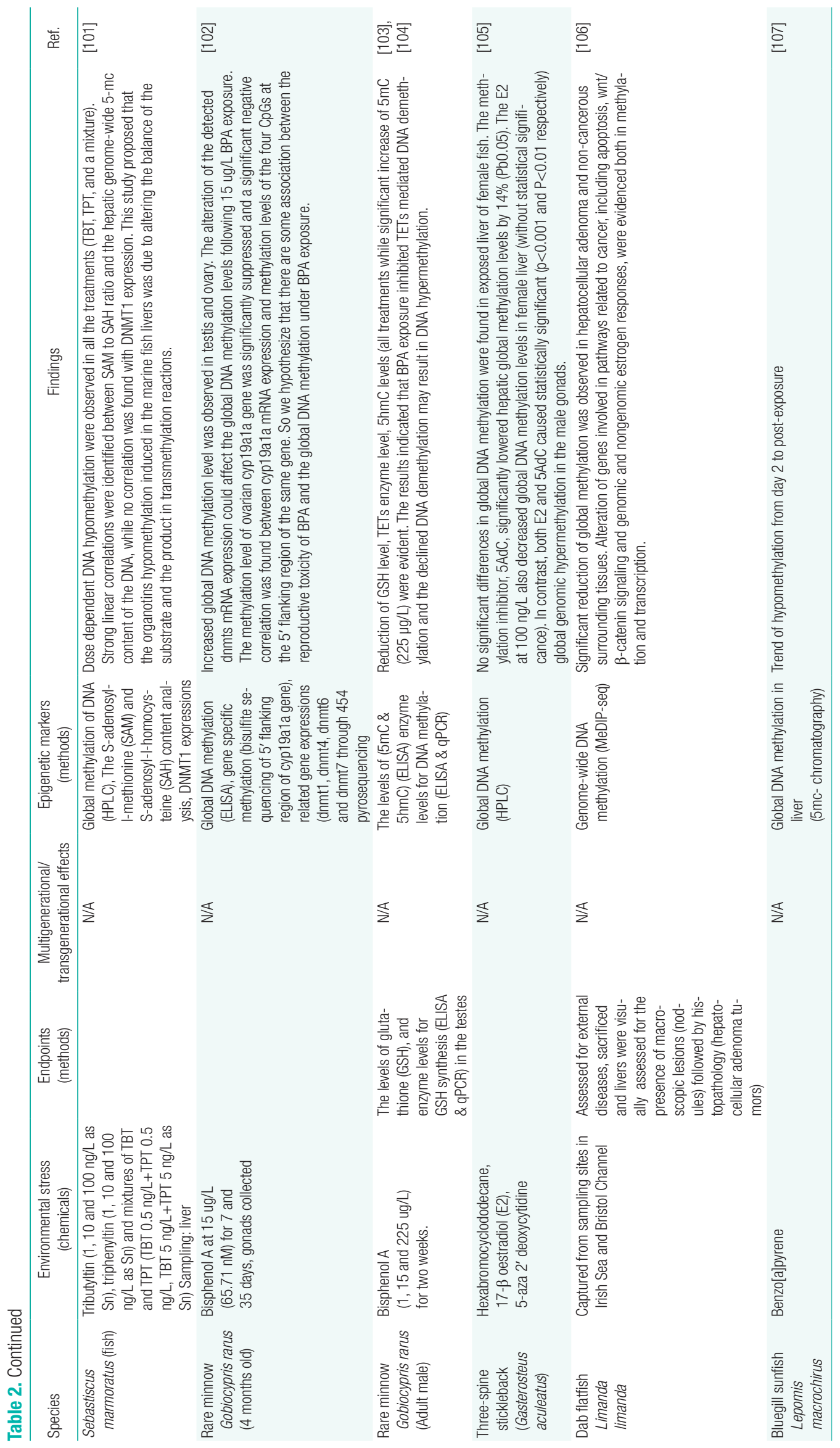




\section{EPIGENETIC PROFILING IN RESPONSE TO ENVIRONMENTAL STRESS IN WILDLIFE SPECIES}

Tables 2 presented the available information on epigenetic profiling in response to environmental chemical exposure in wildlife species, which are mostly ecological and ecotoxicological relevant non-model organisms. Most of studies using wildlife species were on DNA methylation.

\section{FUTURE DIRECTION: EPIGENETICS IN ECOLOGICAL RISK ASSESSMENT}

Various environmental factors, including chemical exposure, can modulate epigenome, the regulator of gene expressions, of several species, including model (Table 1) and non-model field organisms (Table 2). Some of the studies reported transgenerational inheritance of the exposure, i.e., epigenetic changes continued in non-exposed progeny. Real efforts are in progress to identify specific epigenetic marks which could provide 'signature of xenobiotic exposure' and linking epigenetic effects with toxicant induced altered phenotypes such as adverse outcomes, increased stress resistance, etc. Nonetheless, huge knowledge gap and challenges need to be overcome to integrate or organize toxicoepigeneics data in adverse outcome pathway (AOP) framework and/or risk assessment processes [7, 108-109].

\section{ACKNOWLEDGMENTS}

This work was supported by the Mid-career Researcher Program (NRF-2017R1A2B3002242) through the National Research Foundation of Korea (NRF) funded by the Ministry of Science and ICT.

\section{REFERENCES}

1. Head JA, Dolinoy DC, Basu N. Epigenetics for ecotoxicologists. Environ Toxicol Chem 2012;31(2):221-227.

2. Casati L, Sendra R, Sibilia V, Celotti F. Endocrine disrupters: the new players able to affect the epigenome. Front Cell Dev Biol 2015;3:37.

3. Vandegehuchte MB, Janssen CR. Epigenetics and its implications for ecotoxicology. Ecotoxicology (London, England) 2011;20(3):607624.

4. Ho DH, Burggren WW. Epigenetics and transgenerational transfer: a physiological perspective. J Exp Biol 2010;213(1):3-16.

5. Esteller M. Epigenetics in Cancer. N Engl J Med 2008;358:1148-1159.

6. Feinberg AP, Tycko B. The history of cancer epigenetics. Nat Rev Cancer 2004; 4(2):143-153.

7. Goodman JI. Incorporation of an epigenetic evaluation into safety assessment: What we first need to know. Curr Opin in Toxicol
2017;3:20-24.

8. Jaenisch R, Bird A. Epigenetic regulation of gene expression: how the genome integrates intrinsic and environmental signals. Nat Genet 2003;33:245-254.

9. West-Eberhard MJ. Phenotypic plasticity and the origins of diversity. Annu Rev Ecol Syst 1989;20:249-278.

10. Dolinoy DC. The agouti mouse model: an epigenetic biosensor for nutritional and environmental alterations on the fetal epigenome. Nutr Rev 2008;66:S7-S11.

11. Hashida S-N, Kitamura K, Mikami T, Kishima Y. Temperature shift coordinately changes the activity and the methylation state of transposon Tam3 in Antirrhinum majus. Plant Physiol 2003;132(3):12071216.

12. Heijmans BT, Tobi EW, Stein AD, Putter H, Blauw GJ, Susser ES, et al. Persistent epigenetic differences associated with prenatal exposure to famine in humans. Proc Natl Acad Sci USA 2008;105(44):1704617049.

13. Kucharski R, Maleszka J, Foret S, Maleszka R. Nutritional Control of Reproductive Status in Honeybees via DNA Methylation. Science 2008(5781); 319:1827-1830.

14. Navarro-Martín L, Viñas J, Ribas L, Díaz N, Gutiérrez A, Di Croce L, et al. DNA Methylation of the Gonadal Aromatase (cyp19a) Promoter Is Involved in Temperature-Dependent Sex Ratio Shifts in the European Sea Bass. PLoS Genet 2011;7(12):e1002447.

15. Baccarelli A, Bollati V. Epigenetics and environmental chemicals. Curr Opin Pediatr 2009;21(2):243-251.

16. Mirbahai L, Chipman JK. Epigenetic memory of environmental organisms. A reflection of lifetime stressor exposures. Mutat Res Genet Toxicol Environ Mutagen 2014;764-765:10-17.

17. Suarez-Ulloa V, Gonzalez-Romero R, Eirin-Lopez JM. Environmental epigenetics: A promising venue for developing next-generation pollution biomonitoring tools in marine invertebrates. Mar Pollut Bull 2015;98(1-2):5-13.

18. Guo SN, Zheng JL, Yuan SS, Zhu, QL. Effects of heat and cadmium exposure on stress-related responses in the liver of female zebrafish: Heat increases cadmium toxicity. The Sci Total Environ 2018 ;618: 1363-1370.

19. Bouwmeester MC, Ruiter S, Lommelaars T, Sippel J, Hodemaekers HM, Brandhof EJ, et al. Zebrafish embryos as a screen for DNA methylation modifications after compound exposure. Toxicol Appl Pharmacol 2016; 291:84-96

20. Gombeau K, Bourdineaud JP, Ravanat JL, Armant O, Camilleri V, Cavalie I, et al. Epigenetic, histopathological and transcriptomic effects following exposure to depleted uranium in adult zebrafish and their progeny. Aquat Toxicol 2017;184:14-25.

21. Wu M, Wu D, Wang C, Guo Z, Li B, Zuo Z. Hexabromocyclododecane exposure induces cardiac hypertrophy and arrhythmia by inhibiting miR-1 expression via up-regulation of the homeobox gene Nkx2.5. J Hazard Mater 2015;302:304-313.

22. Gombeau K, Pereira S, Ravanat J.L, Camilleri V, Cavalie I, Bourdineaud J.P, et al. Depleted uranium induces sex- and tissue-specific methylation patterns in adult zebrafish. J Environ Radioact 2016; 154, 25-33.

23. Wirbisky-Hershberger SE, Sanchez OF, Horzmann KA, Thanki D, Yuan C, Freeman JL. Atrazine exposure decreases the activity of 
DNMTs, global DNA methylation levels, and dnmt expression. Food Chem Toxicol 2017;109(Pt 1), 727-734.

24. Stromqvist M, Tooke N, Brunstrom B. DNA methylation levels in the 5' flanking region of the vitellogenin I gene in liver and brain of adult zebrafish (Danio rerio)-sex and tissue differences and effects of 17 alpha-ethinylestradiol exposure. Aquat Toxicol 2010;98(3): 275-281.

25. Fang X, Thornton C, Scheffler BE, Willett KL. Benzo[a]pyrene decreases global and gene specific DNA methylation during zebrafish development. Environ Toxicol Pharmacol 2013;36(1):40-50.

26. Corrales J, Thornton C, White M, Willett KL. Multigenerational effects of benzo[a]pyrene exposure on survival and developmental deformities in zebrafish larvae. Aquat Toxicol 2014;148:16-26.

27. Dorts J, Falisse E, Schoofs E, Flamion E, Kestemont P, Silvestre F. DNA methyltransferases and stress-related genes expression in zebrafish larvae after exposure to heat and copper during reprogramming of DNA methylation. Sci Rep 2016;6:34254

28. Liu Y, Zhang Y, Tao S, Guan Y, Zhang T, Wang Z. Global DNA methylation in gonads of adult zebrafish Danio rerio under bisphenol A exposure. Ecotoxicol Environ Saf 2016; 130:124-132.

29. Ma YB, Jia PP, Junaid M, Yang L, Lu CJ, Pei DS. Reproductive effects linked to DNA methylation in male zebrafish chronically exposed to environmentally relevant concentrations of di-(2-ethylhexyl) phthalate. Environ Pollut 2018; 237:1050-1061.

30. McGee SP, Cooper EM, Stapleton HM, Volz DC. Early zebrafish embryogenesis is susceptible to developmental TDCPP exposure. Environ Health Perspect 2012;120(11):1585-1591.

31. Lombo M, Fernandez-Diez C, Gonzalez-Rojo S, Navarro C, Robles V, Herraez MP. Transgenerational inheritance of heart disorders caused by paternal bisphenol A exposure. Environ Pollut 2015;206:667-678.

32. Olsvik PA, Williams TD, Tung HS, Mirbahai L, Sanden M, Skjaerven $\mathrm{KH}$, Ellingsen S. Impacts of TCDD and MeHg on DNA methylation in zebrafish (Danio rerio) across two generations. Comp Biochem Physiol C Toxicol Pharmacol 2014;165:17-27.

33. Aluru N, Kuo E, Helfrich LW, Karchner SI, Linney EA, Pais JE,et al. Developmental exposure to 2,3,7,8-tetrachlorodibenzo-p-dioxin alters DNA methyltransferase (dnmt) expression in zebrafish (Danio rerio). Toxicol Appl Pharmacol 2015;284(2):142-151.

34. Kamstra JH, Sales LB, Aleström P, Legler J. Differential DNA methylation at conserved non-genic elements and evidence for transgenerational inheritance following developmental exposure to mono(2-ethylhexyl) phthalate and 5-azacytidine in zebrafish. Epigenetics Chromatin 2017;10:20.

35. Qian Y, Wang C, Wang J, Zhang X, Zhou Z, Zhao M, et al. Fipronil-induced enantioselective developmental toxicity to zebrafish embryo-larvae involves changes in DNA methylation. Sci Rep 2017;7.

36. Knecht AL, Truong L, Marvel SW, Reif DM, Garcia A, Lu C, et al. Transgenerational inheritance of neurobehavioral and physiological deficits from developmental exposure to benzo[a]pyrene in zebrafish. Toxicol Appl Pharmacol 2017; 329:148-157.

37. Sanchez OF, Lee J, Yu King Hing N, Kim SE, Freeman JL, Yuan C. Lead $(\mathrm{Pb})$ exposure reduces global DNA methylation level by noncompetitive inhibition and alteration of dnmt expression. Metallomics 2017; 9(2):149-160.
38. Jenny MJ, Aluru N, Hahn ME. Effects of short-term exposure to 2,3,7,8-tetrachlorodibenzo-p-dioxin on microRNA expression in zebrafish embryos. Toxicol Appl Pharmacol 2012;264(2):262-273.

39. Laing LV, Viana J, Dempster EL, Trznadel M, Trunkfield LA, Uren Webster TM, et al. Bisphenol A causes reproductive toxicity, decreases dnmtl transcription, and reduces global DNA methylation in breeding zebrafish (Danio rerio). Epigenetics 2016;11(7):526538.

40. Li D, Lu C, Wang J, Hu W, Cao Z, Sun D, et al. Developmental mechanisms of arsenite toxicity in zebrafish (Danio rerio) embryos. Aquat Toxicol 2009;91(3):229-237.

41. Xu QH, Guan P, Zhang T, Lu C, Li G, Liu JX. Silver nanoparticles impair zebrafish skeletal and cardiac myofibrillogenesis and sarcomere formation. Aquat Toxicol 2018;200:102-113.

42. Zheng JL, Guo SN, Yuan SS, Xia H., Zhu QL, Lv Z.M. Preheating mitigates cadmium toxicity in zebrafish livers: Evidence from promoter demethylation, gene transcription to biochemical levels. Aquat Toxicol 2017;190:104-111.

43. Zhao F, Wei P, Wang J, Yu M, Zhang X, Tian H, et al. Estrogenic effects associated with bisphenol a exposure in male zebrafish (Danio rerio) is associated with changes of endogenous $17 \beta$-estradiol and gene specific DNA methylation levels. GenComp Endocrinol 2017a;252:27-35.

44. Mirbahai L, Williams TD, Zhan H, Gong Z, Chipman JK. Comprehensive profiling of zebrafish hepatic proximal promoter $\mathrm{CpG}$ island methylation and its modification during chemical carcinogenesis. BMC Genomics 2011a;12:3.

45. Lee J, Kho Y, Kim PG, Ji K. Exposure to bisphenol S alters the expression of microRNA in male zebrafish. Toxicol Appl Pharmacol 2018a; 338:191-196.

46. Wang X, Zhou S, Ding X, Zhu G, Guo J. Effect of triazophos, fipronil and their mixture on miRNA expression in adult zebrafish. J Environ Sci Health B 2010;45(7):648-657.

47. Huang H, Zhang K, Zhou Y, Ding X, Yu L, Zhu G, Guo J. MicroRNA-155 targets cyb561d2 in zebrafish in response to fipronil exposure. Environ Toxicol 2014;31(7):877-886.

48. Huang CX, Chen N, Wu XJ, Huang CH, He Y, Tang R, et al. The zebrafish miR-462/miR-731 cluster is induced under hypoxic stress via hypoxia-inducible factor lalpha and functions in cellular adaptations. FASEB J 2015;29(12):4901-4913.

49. Aluru N, Deak KL, Jenny MJ, Hahn ME. Developmental exposure to valproic acid alters the expression of microRNAs involved in neurodevelopment in zebrafish. Neurotoxicol Teratol 2013;40:46-58.

50. Soares AR, Pereira PM, Ferreira V, Reverendo M, Simoes J, Bezerra AR, et al. Ethanol exposure induces upregulation of specific microRNAs in zebrafish embryos. Toxicol Sci 2012;127(1):18-28.

51. Zhang L, Li YY, Zeng HC, Wei J, Wan YJ, Chen J, et al. MicroRNA expression changes during zebrafish development induced by perfluorooctane sulfonate. J Appl Toxicol 2011;31(3):210-222.

52. Zhao J, Xu T, Yin D, Zhang B, Bai J. The Regulatory Roles of MicroRNA in Effects of 2,2'4,4'-Tetrabromodiphenyl Ether (BDE47) on the Transcriptome of Zebrafish Larvae. PLoS One 2017b;12(1): e0169599.

53. Santangeli S, Maradonna F, Gioacchini G, Cobellis G, Piccinetti CC, Dalla Valle L, et al. BPA-Induced Deregulation Of Epigenetic Pat- 
terns: Effects On Female Zebrafish Reproduction. Sci Rep 2016; 6:21982.

54. Rechavi O, Houri-Ze'evi L, Anava S, Goh WS, Kerk SY, Hannon G.J et al. Starvation-induced transgenerational inheritance of small RNAs in C. elegans. Cell 2014;158(2):277-287.

55. Taki FA, Pan X, Lee MH, Zhang B. 2014. Nicotine exposure and transgenerational impact: a prospective study on small regulatory microRNAs. Sci Rep 2014;4:7513.

56. Zhao Y, Wu Q, Wang D. An epigenetic signal encoded protection mechanism is activated by graphene oxide to inhibit its induced reproductive toxicity in Caenorhabditis elegans. Biomaterials 2016a;79:15-24.

57. Zhao Y, Yang J, Wang D. A MicroRNA-Mediated Insulin Signaling Pathway Regulates the Toxicity of Multi-Walled Carbon Nanotubes in Nematode Caenorhabditis elegans. Sci Rep 2016b;6:23234.

58. Tauffenberger A, Parker JA. Heritable transmission of stress resistance by high dietary glucose in Caenorhabditis elegans. PLoS Genet 2014;10(5):e1004346.

59. Rudgalvyte M, Peltonen J, Lakso M, Wong G. Chronic MeHg exposure modifies the histone H3K4me3 epigenetic landscape in Caenorhabditis elegans. Comp Biochem Physiol C Toxicol Pharmacol 2017;191:109-116.

60. Yang J, Chatterjee N, Kim Y, Roh JY, Kwon JH, Park MS, et al. Histone methylation-associated transgenerational inheritance of reproductive defects in Caenorhabditis elegans exposed to crude oil under various exposure scenarios. Chemosphere 2018;200:358-365.

61. Camacho J, Truong L, Kurt Z, Chen YW, Morselli M, Gutierrez G, et al. The memory of environmental chemical exposure in C. elegans is dependent on the jumonji demethylases jmjd-2 and jmjd-3/utx1. Cell Rep 2018;23(8):2392-2404.

62. Klosin A, Casas E, Hidalgo-Carcedo C, Vavouri T, Lehner B. Transgenerational transmission of environmental information in C. elegans. Science (New York, N.Y.) 2017;356:320-323.

63. Chandra S, Pandey A, Chowdhuri DK. MiRNA profiling provides insights on adverse effects of $\mathrm{Cr}(\mathrm{VI})$ in the midgut tissues of Drosophila melanogaster. J Hazard Mater 2015;283:558-567.

64. Seong KM, Coates BS, Kim DH, Hansen AK, Pittendrigh BR. Differentially expressed microRNAs associated with changes of transcript levels in detoxification pathways and DDT-resistance in the Drosophila melanogaster strain 91-R. PloS One 2018;13:e196518.

65. Chen S, McKinney GJ, Nichols KM, Colbourne JK, Sepulveda MS. Novel cadmium responsive microRNAs in Daphnia pulex. Environ Sci Technol 2015;49(24):14605-14613.

66. Asselman J, De Coninck DI, Vandegehuchte MB, Jansen M, Decaestecker E, De Meester L, et al. Global cytosine methylation in Daphnia magna depends on genotype, environment, and their interaction. Environ Toxicol Chem 2015;34(5):1056-1061.

67. Menzel S, Bouchnak R, Menzel R, Steinberg CE. Dissolved humic substances initiate DNA-methylation in cladocerans. Aquat Toxicol 2011;105(3-4):640-642.

68. Vandegehuchte MB, Lemiere F, Janssen CR. Quantitative DNAmethylation in Daphnia magna and effects of multigeneration $\mathrm{Zn}$ exposure. Comp Biochem Physiol C Toxicol Pharmacol 2009b;150(3):343-348.

69. Vandegehuchte MB, Kyndt T, Vanholme B, Haegeman A, Gheysen G,
Janssen CR. Occurrence of DNA methylation in Daphnia magna and influence of multigeneration Cd exposure. Environ Int 2009a; 35(4):700-706.

70. Asselman J, De Coninck DI, Beert E, Janssen CR, Orsini L, Pfrender $\mathrm{ME}$, et al. Bisulfite sequencing with Daphnia highlights a role for epigenetics in regulating stress response to microcystis through preferential differential methylation of serine and threonine amino acids. Environ Sci Technol 2017;51(2):924-931.

71. Athanasio CG, Sommer U, Viant MR, Chipman JK, Mirbahai, L. Use of 5-azacytidine in a proof-of-concept study to evaluate the impact of pre-natal and post-natal exposures, as well as within generation persistent DNA methylation changes in Daphnia. Ecotoxicology 2018;27(5):556-568.

72. Trijau M, Asselman J, Armant O, Adam-Guillermin C, De Schamphelaere KAC, Alonzo F. Transgenerational DNA Methylation Changes in Daphnia magna Exposed to Chronic gamma Irradiation. Environ Sci Technol 2018;52(7):4331-4339.

73. Norouzitallab P, Baruah K, Vandegehuchte M, Van Stappen G, Catania F, Vanden Bussche J, et al. Environmental heat stress induces epigenetic transgenerational inheritance of robustness in parthenogenetic Artemia model. FASEB J 2014;28(8):3552-3563.

74. Pestana JLT, Novais SC, Norouzitallab P, Vandegehuchte MB, Bossier P, De Schamphelaere KAC. Non-lethal heat shock increases tolerance to metal exposure in brine shrimp. Environ Res 2016; 151, 663-670.

75. Bao Y, Zhang L, Dong Y, Lin Z. Identification and comparative analysis of the Tegillarca granosa haemocytes microRNA transcriptome in response to $\mathrm{Cd}$ using a deep sequencing approach. PloS One 2017;9(4):e93619.

76. Gonzalez-Romero R, Suarez-Ulloa V, Rodriguez-Casariego J, GarciaSouto D, Diaz G, Smith A, et al. Effects of Florida Red Tides on histone variant expression and DNA methylation in the Eastern oyster Crassostrea virginica. Aquat Toxicol 2017;186:196-204.

77. Rondon R, Grunau C, Fallet M, Charlemagne N, Sussarellu R, Chaparro C, et al. Effects of a parental exposure to diuron on Pacific oyster spat methylome. Environ Epigenet 2017;3(1):dvx004-dvx004.

78. Sussarellu R, Lebreton M, Rouxel J, Akcha F, Riviere G. Copper induces expression and methylation changes of early development genes in Crassostrea gigas embryos. Aquat Toxicol 2018;196:70-78.

79. Huo D, Sun L, Li X, Ru X, Liu S, Zhang L, et al. Differential Expression of miRNAs in the Respiratory Tree of the Sea Cucumber Apostichopus japonicus Under Hypoxia Stress. G3 (Bethesda, Md.) 2017;7(11):3681-3692.

80. Ding G, Wang L, Zhang J, Wei Y, Wei L, Li Y, et al. Toxicity and DNA methylation changes induced by perfluorooctane sulfonate (PFOS) in sea urchin Glyptocidaris crenularis. Chemosphere 2015;128:225230.

81. Dimond JL, Roberts SB. Germline DNA methylation in reef corals: patterns and potential roles in response to environmental change. Mol Ecol 2016;25(8):1895-1904.

82. Martinez-Guitarte JL, Planello R, Morcillo G. Overexpression of long non-coding RNAs following exposure to xenobiotics in the aquatic midge Chironomus riparius. Aquat Toxicol 2012;110-111:84-90.

83. Lee SW, Chatterjee N, Im JE, Yoon D, Kim S, Choi J. Integrated approach of eco-epigenetics and eco-metabolomics on the stress re- 
sponse of bisphenol-A exposure in the aquatic midge Chironomus riparius. Ecotoxicol Environ Saf 2018b;163:111-116.

84. Oppold A, Kress A, Vanden Bussche J, Diogo JB, Kuch U, Oehlmann J, et al. Epigenetic alterations and decreasing insecticide sensitivity of the Asian tiger mosquito Aedes albopictus. Ecotoxicol Environ Saf 2015;122:45-53.

85. Pierron F, Bureau du Colombier S, Moffett A, Caron A, Peluhet L, Daffe G, et al. Abnormal ovarian DNA methylation programming during gonad maturation in wild contaminated fish. Environ Sci Technol 2014;48(9):11688-11695.

86. Timme-Laragy AR, Meyer JN, Waterland RA, Di Giulio RT. Analysis of CpG methylation in the killifish CYP1A promoter. Comp Biochem Physiol C Toxicol Pharmacol 2005; 141, 406-411.

87. Aluru N, Karchner SI, Hahn ME. Role of DNA methylation of AHR1 and AHR2 promoters in differential sensitivity to PCBs in Atlantic Killifish, Fundulus heteroclitus. Aquat Toxicol 2011;101:288-294.

88. Bizuayehu TT, Johansen SD, Puvanendran V, Toften H, Babiak I. Temperature during early development has long-term effects on microRNA expression in Atlantic cod. BMC genomics 2015;16:305.

89. Ku P, Wang C, Nie X, Ou R, Li K. Regulation of pregnane-X-receptor and microRNAs on detoxification-related genes expressions in Mugilogobius abei under the exposure to diclofenac. Environ Pollut 2018;233:395-406.

90. Zhang X, Li H, Qiu Q, Qi Y, Huang D, Zhang, Y. 2,4-Dichlorophenol induces global DNA hypermethylation through the increase of Sadenosylmethionine and the upregulation of DNMTs mRNA in the liver of goldfish Carassius auratus. Comp Biochem Physiol C Toxicol Pharmacol 2014;160:54-59.

91. Alvarado S, Mak T, Liu S, Storey KB, Szyf M. Dynamic changes in global and gene-specific DNA methylation during hibernation in adult thirteen-lined ground squirrels, Ictidomys tridecemlineatus. J Exp Biol 2015;218(Pt 11):1787-1795.

92. Biggar, Y and Storey, KB. Global DNA modifications suppress transcription in brown adipose tissue during hibernation. Cryobiology 2014;69(2):333-338.

93. Pilsner JR, Lazarus AL, Nam DH, Letcher RJ, Sonne C, Dietz R, et al. Mercury-associated DNA hypomethylation in polar bear brains via the LUminometric Methylation Assay: a sensitive method to study epigenetics in wildlife. Mol Ecol 2010;19:307-314.

94. Basu N, Head J, Nam DH, Pilsner JR, Carvan MJ, Chan HM, et al. Effects of methylmercury on epigenetic markers in three model species: mink, chicken and yellow perch. Comp Biochem Physiol C Toxicol Pharmacol 2013;157:322-327.

95. Weyrich A, Lenz D, Jeschek M, Chung TH, Rubensam K, Goritz F, et al. Paternal intergenerational epigenetic response to heat exposure in male Wild guinea pigs. Mol Ecol 2016;25(8):1729-1740.

96. Nilsen FM, Parrott BB, Bowden JA, Kassim BL, Somerville SE, Bryan TA, et al. Global DNA methylation loss associated with mercury contamination and aging in the American alligator (Alligator mis- sissippiensis). Sci Total Environ 2016;545-546:389-397.

97. Kure EH, Saebo M, Stangeland AM, Hamfjord J, Hytterod S, Heggenes J, et al. Molecular responses to toxicological stressors: profiling microRNAs in wild Atlantic salmon (Salmo salar) exposed to acidic aluminum-rich water. Aquat Toxicol 2013;138-139:98-104.

98. Santoyo MM, Flores CR, Torres AL, Wrobel K, Wrobel K. Global DNA methylation in earthworms: a candidate biomarker of epigenetic risks related to the presence of metals/metalloids in terrestrial environments. Environ Pollut 2011;159(10):2387-2392.

99. Marsh AG, Pasqualone AA. DNA methylation and temperature stress in an Antarctic polychaete, Spiophanes tcherniai. Front Physiol 2014;5:173.

100. Fellous A, Favrel P, Riviere G. Temperature influences histone methylation and mRNA expression of the Jmj-C histone-demethylase orthologues during the early development of the oyster Crassostrea gigas. Mar Genomics 2015;19:23-30.

101. Wang Y, Wang C, Zhang J, Chen Y, Zuo Z. DNA hypomethylation induced by tributyltin, triphenyltin, and a mixture of these in Sebastiscus marmoratus liver. Aquat Toxicol 2009;95:93-98.

102. Liu Y, Yuan C, Chen S, Zheng Y, Zhang Y, Gao J, et al. Global and cyp19ala gene specific DNA methylation in gonads of adult rare minnow Gobiocypris rarus under bisphenol A exposure. Aquat Toxicol 2014;156:10-16.

103. Yuan C, Zhang Y, Liu Y, Wang S, Wang Z. DNA demethylation mediated by down-regulated TETs in the testes of rare minnow Gobiocypris rarus under bisphenol A exposure. Chemosphere 2017; 171:355-361.

104. Yuan C, Zhang Y, Liu Y, Zhang T, Wang Z. Enhanced GSH synthesis by Bisphenol A exposure promoted DNA methylation process in the testes of adult rare minnow Gobiocypris rarus. Aquat Toxicol 2016;178:99-105.

105. Aniagu SO, Williams TD, Allen Y, Katsiadaki I, Chipman JK. Global genomic methylation levels in the liver and gonads of the threespine stickleback (Gasterosteus aculeatus) after exposure to hexabromocyclododecane and 17-beta oestradiol. Environ Int 2008;34(3):310-317.

106. Mirbahai L, Yin G, Bignell JP, Li N, Williams T.D, Chipman JK. DNA methylation in liver tumorigenesis in fish from the environment. Epigenetics 2011b;6(11):1319-1333.

107. Shugart LR. 5-Methyl deoxycytidine content of DNA from bluegill sunfish (Lepomis macrochirus) exposed to benzo[a]pyrene. Environ Toxicol Chem 1990; 9:205-208.

108. Angrish MM, Allard P, McCullough SD, Druwe IL, Helbling Chadwick L, Hines E, et al. Epigenetic applications in adverse outcome pathways and environmental risk evaluation. Environ Health Perspect 2018;126(4):045001

109. Vandegehuchte MB, Janssen CR. Epigenetics in an ecotoxicological context. Mutat Res Genet Toxicol Environ Mutagen 2014;764765:36-45. 